\title{
Relation of Sociodemographics and Personal Hygiene on Different Childhood Dermatoses \\ Gauchan $\mathrm{E},{ }^{1}$ Kumar $A,{ }^{2}$ BK G, ${ }^{1}$ Thapa $P,{ }^{3}$ Pun J ${ }^{2}$
}

\author{
${ }^{1}$ Department of Pediatrics \\ ${ }^{2}$ Department of Dermatology \\ ${ }^{3}$ Department of Psychiatry \\ Manipal College of Medical Sciences \\ Fulbari, Pokhara
}

\section{Corresponding Author}

Eva Gauchan

Department of Pediatrics

Manipal College of Medical Sciences

Fulbari, Pokhara

E-mail: evagauchan@gmail.com

\section{Citation}

Gauchan E, Kumar A, BK G, Thapa P, Pun J. Relation of Sociodemographics and Personal Hygiene on Different Childhood Dermatoses. Kathmandu Univ Med J 2015;49(1):29-33.

\section{ABSTRACT}

\section{Background}

Skin diseases in children contribute to significant morbidity and psychological distress. Infective dermatoses are one of the major dermatoses in children. Low socioeconomic status, overcrowding and poor personal hygiene has been linked to skin diseases.

\section{Objective}

To find out the prevalence of infectious skin disease in children, rate of transmissible skin disease and association of sociodemographic factors and personal hygiene on infective childhood dermatoses.

\section{Method}

This was a cross-sectional study conducted in the Pediatric and Dermatology Department, Manipal Teaching Hospital, Pokhara, Nepal. A total of 226 patients were examined over a period of one year. Relation of sociodemographics, crowding and personal hygiene on skin disease were assessed.

\section{Result}

The most common category was Infections and Infestations (51.3\%) followed by Dermatitis (27.9\%) . Transmissible skin disease was seen in $49.6 \%$. Low socioeconomic status and overcrowding were associated with increased risk for infective dermatoses.

\section{Conclusion}

Skin disease in children constitutes a public health problem. Improving the socioeconomic status and personal hygiene can help to reduce the incidence of skin disease in children.

\section{KEY WORDS}

Infections and infestations, personal hygiene, sociodemographics 


\section{INTRODUCTION}

Skin diseases are a common cause of hospital visits worldwide, occurring in both rural and urban populations, affecting both young and old. The type of disease can, however vary according to the regions; eczemas are the commonest skin problems in developed countries while infections and infestations are common in the developing world. ${ }^{1}$

According to the annual report of Ministry of Health and Populations in Nepal, skin diseases are a major cause of morbidity, with $\sim 2,700,000$ and $2,680,000$ outpatient visits for skin diseases in 2009 and 2010. ${ }^{2,3}$ In Western Nepal, the prevalence of skin disease in children was found to be $13.46 \%{ }^{4}$ Several studies conducted in India have quoted a prevalence of skin disease of $15.4 \%-20.2 \% .6,6$ Skin infections are common during school-going age due to constant exposure to subclinical infectious cases by intermingling with each other. ${ }^{7}$ Lower socioeconomic status, overcrowding, poor personal hygiene, lack of parental education, poor awareness have all been linked to increased incidence of skin infections in children. ${ }^{1}$

The aim of this study was to find the commonest skin disease in children in our part of the world, rate of transmissible skin disease and its' relation to sociodemographics and personal hygiene.

\section{METHODS}

This was a descriptive, cross-sectional study conducted in the Pediatric and Dermatology Outpatient Department, Manipal Teaching Hospital, Pokhara, Nepal during January 2013 to December 2013. The study was passed through the Hospital Ethical Review Committee. Children between the ages of one month to 15 years who attended the Outpatient Department for skin problems were included in the study after taking informed consent from the attendants. Infants less than one month of age and who had skin lesions present from the time of birth were excluded. All cases were referred to Dermatology OPD and were diagnosed by a Consultant Dermatologist. History and clinical findings were noted in a pre-designed proforma.

The patients were then divided into two groups on the basis of their diagnosis.

Group I: Patients having "Infections and Infestations".

Group II: Patients with "Other dermatoses".

Sociodemographic data included age and sex, educational status and occupation of the parents, gross monthly income, family size, type of house, number of rooms, birth order, month of presentation, pets ownership, similar family history, area of residence, socioeconomic status, crowding index, bathing frequency, use of soap for bathing, towel sharing, frequency of changing underwear and nail trimming. Socioeconomic status (SES) was categorized according to Kuppuswamy's scale modified in the context of Nepal into Upper Class (I), Upper Middle Class (II), Lower Middle Class (III), Upper Lower Class (IV) and Lower Class (V). ${ }^{8}$ Overcrowding was defined if two or more people had to share a bedroom in a ratio of 2:1 or more. ${ }^{9,10}$

Statistical analysis: Data were analyzed using SPSS version 19. Data were presented in frequencies and percentages. Statistical methods used were Chi-square test, Kendall Tau and Pearson's co-relation co-efficient, where required. A $p$-value of $<0.05$ was considered as significant.

\section{RESULTS}

There were a total of 226 patients who visited the Pediatric and Dermatology Outpatient Department during the period of study. The most common age for presentation was one to five years ( $n=107,47.3 \%$ ) followed by more than five years of age $(n=88,38.9 \%)$. The mean age was 62.1 months (range 1.5-180 months). Male: female ratio was 1.53:1. Fig. 1 shows the age and sex distribution of skin disease in children.

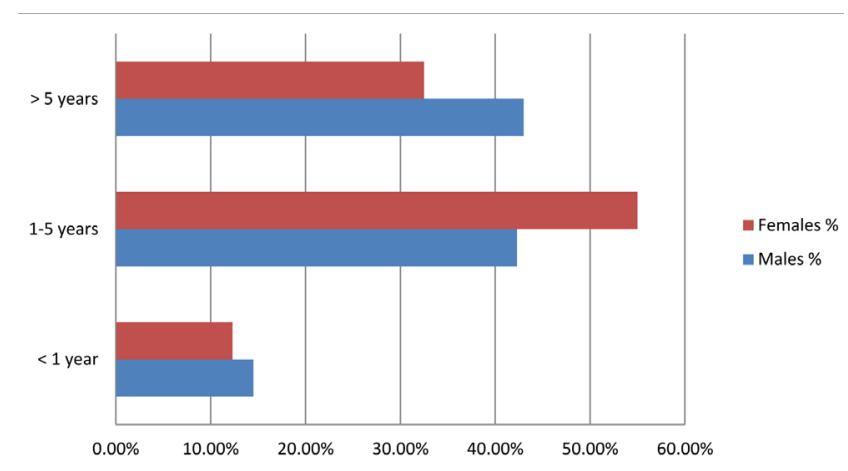

Figure 1. Age and sex distribution of patients with skin disease

Similar kind of skin disease in the past was found in $25.2 \%$ of the children and $21.2 \%$ had received medical treatment for the condition. Most number of visits were during January $(n=41,18.1 \%)$ and July $(n=39,17.3 \%)$.The commonest disease in January was contact dermatitis ( $n=5 / 41,12.1 \%$ ) and in July was impetigo ( $n=7 / 39,17.9 \%)$. Among the 226 patients, $60.6 \%$ were first-born children; the risk for skin disease showed a progressive decline with increased order of birth (Table 1 ).

Infections and infestations were the most common diagnosis ( $n=116 ; 51.3 \%$ ) followed by dermatitis $(n=63$, $27.9 \%)$. In children less than one year of age, the most common diagnoses were contact dermatitis $(n=4 ; 12.9 \%)$, seborrheic dermatitis $(n=4 ; 12.9 \%)$ and miliria rubra $(n=4$; $12.9 \%)$ followed by impetigo $(n=3 ; 9.7 \%)$ and tinea capitis $(n=3 ; 9.7 \%)$. In children $1-5$ years of age, commonest diagnosis was contact dermatitis $(n=16 ; 15 \%)$ followed by scabies $(n=13 ; 12.1 \%)$ and impetigo $(n=13 ; 12.1 \%)$. Above 5 years of age, the commonest diagnosis was impetigo $(n=9$; $10.2 \%)$ followed by tinea capitis $(n=6 ; 6.8 \%)$, P. versicolor $(n=6 ; 6.8 \%)$ and wart $(n=6 ; 6.8 \%)$. The commonest 
Table 1. Sociodemographics and hygiene profile of children with skin disease

\begin{tabular}{|c|c|c|c|c|}
\hline Characteristics & $\mathrm{N}$ & $\begin{array}{l}\text { Group I } \\
\text { N (\%) }\end{array}$ & $\begin{array}{l}\text { Group II } \\
\mathbf{N}(\%)\end{array}$ & p-value \\
\hline \multicolumn{5}{|l|}{ Birth Order } \\
\hline $1 s t$ & 136 & $72(52.9)$ & $64(47)$ & \multirow{3}{*}{0.779} \\
\hline & 75 & $36(48)$ & $39(52)$ & \\
\hline Subsequent & 15 & $8(53.3)$ & $7(46.6)$ & \\
\hline \multicolumn{5}{|l|}{ Father's educational status } \\
\hline$<$ Class VI & 30 & $18(60)$ & $12(40)$ & \multirow[t]{2}{*}{0.307} \\
\hline$>$ Class VI & 196 & $98(50)$ & $98(50)$ & \\
\hline \multicolumn{5}{|l|}{ Mother's educational status } \\
\hline$<$ Class VI & 46 & $28(60)$ & $18(40)$ & \multirow[t]{2}{*}{0.147} \\
\hline$>$ Class VI & 180 & $88(49)$ & $92(51)$ & \\
\hline \multicolumn{5}{|l|}{ Father's occupation } \\
\hline Business & 50 & $23(46)$ & $27(54)$ & \multirow{7}{*}{0.326} \\
\hline Service & 42 & $21(50)$ & $21(50)$ & \\
\hline Working abroad & 60 & $28(46.7)$ & $32(53.3)$ & \\
\hline Farming/Labour & 34 & $21(61.7)$ & $13(38.2)$ & \\
\hline Others & 29 & $15(51.8)$ & $14(48.2)$ & \\
\hline Student & 1 & 0 & $1(100)$ & \\
\hline Unemployed & 10 & $8(80)$ & $2(20)$ & \\
\hline \multicolumn{5}{|l|}{ Mother's occupation } \\
\hline Housewife & 169 & $95(56.2)$ & $74(43.7)$ & \multirow{3}{*}{0.035} \\
\hline Working outside the house & 53 & $19(36)$ & $34(64)$ & \\
\hline Student & 4 & $2(50)$ & $2(50)$ & \\
\hline \multicolumn{5}{|l|}{ Monthly income } \\
\hline Refused to say & 6 & $5(83.3)$ & $1(16.6)$ & \multirow{5}{*}{0.151} \\
\hline$<10,000$ & 35 & $22(62.8)$ & $13(37.1)$ & \\
\hline $10,000-30,000$ & 114 & $53(46.4)$ & $61(53.5)$ & \\
\hline $30,000-60,000$ & 64 & $31(48.4)$ & $33(51.5)$ & \\
\hline$>60,000$ & 7 & $5(71.4)$ & $2(28.5)$ & \\
\hline \multicolumn{5}{|l|}{ Type of house } \\
\hline Kutcha & 42 & $22(52.3)$ & $20(47.6)$ & \\
\hline Pucca & 184 & $94(51.1)$ & $90(48.9)$ & 0.88 \\
\hline Overcrowding & & & & \\
\hline Yes & 45 & $27(60)$ & $18(40)$ & \\
\hline No & 181 & $89(49.1)$ & $92(50.8)$ & 0.030 \\
\hline Residence & & & & \\
\hline Urban & 136 & $72(52.9)$ & $64(47.1)$ & \\
\hline Rural & 90 & $44(48.8)$ & $46(51.1)$ & 0.55 \\
\hline Family size & & & & \\
\hline$\leq 5$ members & 181 & 99 (54.6) & $82(45.3)$ & \\
\hline$>5$ members & 45 & $17(37.7)$ & $28(62.2)$ & 0.020 \\
\hline Socioeconomic status & & & & \\
\hline Upper class (I) & 6 & $3(50)$ & $3(50)$ & \\
\hline Upper middle class (II) & 72 & $31(43)$ & $41(56.9)$ & \\
\hline Lower middle class (III) & 96 & $49(51)$ & 47 (49) & 0.030 \\
\hline Upper lower class (IV) & 44 & $27(61.3)$ & $17(38.6)$ & \\
\hline Lower class (V) & 8 & $6(75)$ & $2(25)$ & \\
\hline Frequency of bathing & & & & \\
\hline Everyday & 6 & $2(33.3)$ & $4(66.6)$ & \\
\hline >Once per week & 92 & $46(50)$ & $46(50)$ & \\
\hline Once per week & 112 & $63(56.2)$ & $49(43.7)$ & 0.211 \\
\hline Less frequently & 16 & $5(31.2)$ & $11(68.7)$ & \\
\hline $\begin{array}{l}\text { Frequency of changing } \\
\text { underwear }\end{array}$ & & & & \\
\hline Daily & 53 & $25(47.1)$ & $28(52.8)$ & \\
\hline >Once per week & 91 & $47(51.6)$ & $44(48.3)$ & \\
\hline Once a week & 80 & $43(53.7)$ & $37(46.2)$ & 0.906 \\
\hline Less frequently & 2 & $1(50)$ & $1(50)$ & \\
\hline Use of soap for bathing & & & & \\
\hline Yes & 222 & $114(51.3)$ & $108(48.6)$ & 0957 \\
\hline No & 4 & $2(50)$ & $2(50)$ & 0.957 \\
\hline Towel sharing & & & & \\
\hline Yes & 171 & $87(50.8)$ & $84(49.2)$ & \\
\hline No & 55 & $29(52.7)$ & $26(47.2)$ & 0.811 \\
\hline Nail trimming & & & & \\
\hline >Once per week & 185 & $91(49.1)$ & $94(50.8)$ & \\
\hline Once a week & 18 & $10(55.5)$ & $8(44.4)$ & 0.326 \\
\hline Less frequently & 23 & 15 (12.9) & $8(7.2)$ & \\
\hline
\end{tabular}

Table 2. Showing distribution of skin diseases encountered:

\begin{tabular}{|c|c|c|c|c|}
\hline Infections \& Infestations & $\mathbf{N}(\%)$ & Other dermatoses & $\mathbf{N}(\%)$ & \\
\hline $\begin{array}{l}\text { a. Bacterial infections } \\
\text { Impetigo } \\
\text { Folliculitis } \\
\text { Cellulitis } \\
\text { Kerion } \\
\text { Echthyma }\end{array}$ & $\begin{array}{l}25(11) \\
1(0.4) \\
2(0.8) \\
2(0.8) \\
1(0.4)\end{array}$ & $\begin{array}{l}\text { Dermatitis } \\
\text { Contact dermatitis } \\
\text { Seborrheic der- } \\
\text { matitis } \\
\text { Seborrheic capitis } \\
\text { Atopic dermatitis } \\
\text { PMLE } \\
\text { Chilblains } \\
\text { Pompholyx } \\
\text { Others }\end{array}$ & $\begin{array}{l}25(11) \\
8(3.5) \\
7(3.0) \\
5(2.2) \\
3(1.3) \\
3(1.3) \\
3(1.3) \\
9(3.9)\end{array}$ & \\
\hline $\begin{array}{l}\text { b. Viral infections } \\
\text { Varicella } \\
\text { Molluscum contagiosum } \\
\text { Wart } \\
\text { Hand-Foot-Mouth disease } \\
\text { Gianotti-Crosti syndrome } \\
\text { Viral exanthema (other) }\end{array}$ & $\begin{array}{l}7(3.0) \\
7(3.0) \\
8(3.5) \\
1(0.4) \\
2(0.8) \\
3(1.3)\end{array}$ & $\begin{array}{l}\text { Hypersensitivity } \\
\text { skin reactions } \\
\text { Acute urticaria } \\
\text { Insect bite reaction } \\
\text { Drug rash } \\
\text { Papular urticaria } \\
\text { Others }\end{array}$ & $\begin{array}{l}8(3.5) \\
5(2.2) \\
2(0.8) \\
1(0.4) \\
2(0.8)\end{array}$ & \\
\hline $\begin{array}{l}\text { c. Fungal infections } \\
\text { T. capitis } \\
\text { T. corporis } \\
\text { T. unguim } \\
\text { T. cruris } \\
\text { P. versicolor } \\
\text { Canidiasis }\end{array}$ & $\begin{array}{l}14(6.1) \\
6(2.6) \\
2(0.8) \\
1(0.4) \\
7(3.0) \\
5(2.2)\end{array}$ & $\begin{array}{l}\text { Dermatoses due to } \\
\text { physical factors } \\
\text { Miliaria rubra } \\
\text { Milia } \\
\text { Others }\end{array}$ & $\begin{array}{l}7(3.0) \\
1(0.4) \\
1(0.4)\end{array}$ & $\begin{array}{l}3 \\
0.4 \\
0.4\end{array}$ \\
\hline \multirow[t]{4}{*}{$\begin{array}{l}\text { d. Parasitic infestations } \\
\text { Scabies }\end{array}$} & $22(9.6)$ & $\begin{array}{l}\text { Non-infective } \\
\text { \& Autoimmune } \\
\text { dermatoses } \\
\text { Vitiligo } \\
\text { Alopecia areata }\end{array}$ & $\begin{array}{l}3(1.3) \\
1(0.4)\end{array}$ & $\begin{array}{l}1.3 \\
0.4\end{array}$ \\
\hline & & $\begin{array}{l}\text { Genodermatoses } \\
\text { Ichthyosis } \\
\text { Epidermal naevus } \\
\text { Melanocytic } \\
\text { naevus }\end{array}$ & $\begin{array}{l}1(0 . .4) \\
1(0.4) \\
1(0.4)\end{array}$ & \\
\hline & & $\begin{array}{l}\text { Papulosquamous } \\
\text { disease } \\
\text { Psoriasis } \\
\text { Lichen planus } \\
\text { Pityriasis rubra } \\
\text { pilaris }\end{array}$ & $\begin{array}{l}1(0.4) \\
1(0.4) \\
1(0.4)\end{array}$ & \\
\hline & & $\begin{array}{l}\text { Miscellaneous } \\
\text { Generalised } \\
\text { pruritus } \\
\text { Acne } \\
\text { Others }\end{array}$ & $\begin{array}{l}4(1.7) \\
1(0.4) \\
5(2.2)\end{array}$ & \\
\hline
\end{tabular}

diagnosis in Group I was impetigo ( $n=25 ; 11 \%)$ followed by scabies ( $n=22 ; 9.6 \%$ ) while in Group II contact dermatitis $(n=25 ; 11 \%)$ followed by seborrheic dermatitis $(n=8 ; 3.5 \%)$ (Table 2).Transmissible skin disease was seen in $(n=112)$ $49.6 \%$ cases with most cases $(n=55,49.1 \%)$ occurring in the 1-5 years age group.

\section{Relation of sociodemographics on infections and} infestations:

In mothers who had lower education (< Class 6), $60.9 \%$ of the children had infections and infestations while $39.1 \%$ had other dermatoses $(p=0.147)$. Similarly, in fathers who had lesser education, infections and infestations occurred in $60 \%$ as compared to $40 \%$ of other dermatoses ( $p=0.307)$. However, this finding was not statistically significant. Infections and infestations were seen to occur more in mothers who were housewives rather than in working mothers $(p=0.035)$. The relation of father's occupation 
to infectious skin disease in children was not statistically significant. In children who lived in overcrowded homes, infections and infestations ( $n=27,60 \%)$ were more common than other dermatoses $(n=18,40 \%) ;(p=0.030)$. Children whose homes were not overcrowded had other dermatoses ( $n=92,50.8 \%)$, which occurred slightly more frequently than infectious disease. Infections and infestations were positively co-related to family size, with increased risk of infections with increase in household population $(p=0.02)$.

In contrast, infections and infestations were inversely correlated with increasing SES $(p=0.03)$ showing that with decrease in SES there was increased chances for infections and infestations. Similarly, the risk for infections and infestations correlated inversely with the number of rooms shared by the household members $(p=0.026)$ with increased risk for infections and infestations seen in households having lesser number of rooms.

\section{Relation of Personal hygiene on infectious dermatoses:}

Infections and infestations occurred in $52.8 \%$ children who took a bath at least once a week as compared to $31.2 \%$ of children who had bath less frequently. Among the children who shared a common towel with other family members, $50.8 \%$ had infections and infestations. Out of 222 children who used soap for bathing, $51.3 \%$ of them had infections and infestations while the rest had non-infective dermatoses. However, in children who trimmed their nails once a week, infections and infestations were less common (49\%) than non-infective dermatoses while in children who trimmed their nails less frequently, infections were seen in $65 \%$ cases as compared to non-infective cases. All these findings were found to be of no significance statistically.

\section{DISCUSSION}

Skin diseases are a common cause for hospital visits in childhood. Different skin diseases affect children, but the presentation depends on several factors like age, sex, sociodemographic factors, overcrowding, personal hygiene, etc. ${ }^{11-12}$ There have been few studies which demonstrate the influence of sociodemographic factors and personal hygiene on skin disease in Nepal. ${ }^{13-15}$

The commonest age for presentation was between 1-5 years. Similar finding was found in others studies. ${ }^{6,16}$ At this age, children are intermingling with their infectious contacts and are constantly exposed to new infections in their neighbourhood due to their lack of awareness. The next common age group was after five years. These children are exposed to a wider variety of infectious etiologies as they are entering into schools at about this time. Infants were seen to be least affected, most probably because they are confined to their homes and are less in contact with infections in the community. Several studies have found infections and infestations to be more common in children coming from rural areas. ${ }^{6,13,17}$ However, in our study it occurred more in the urban population ( $n=136$, $60.2 \%)$ whereas in the rural population it was seen to be less ( $n=90,39.8 \%)$. The reason could be that our hospital being a non-governmental institute is favored more by the urban population, while the rural population still prefers the regional hospital. The most common diagnosis was infections and infestations ( $n=116,51.3 \%)$ followed by dermatitis ( $n=63,27.8 \%$ ); which was also found in other studies. ${ }^{6,16,18}$ Impetigo $(n=25,11 \%)$ was found to be the commonest among the infectious cause as in other studies. ${ }^{6,11,13,16,18-19}$ Memon et al found scabies to be the commonest amongst the infectious disease (45.5\%). ${ }^{17}$ However in our study scabies was seen in $(n=22) 9.6 \%$ cases only. Negi et al has found Pediculosis capitis as the commonest infection in their study. ${ }^{20}$ However we did not find any case of pediculosis. This could indicate the improved hair hygiene in children in our region. Among the non-infective dermatoses, the commonest was contact dermatitis ( $n=25,11 \%)$. This constitutes (25/63) 39.6\% of the dermatitis group. In our study, there were only five cases $(7.9 \%)$ of atopic dermatitis. Balai et al has found atopic dermatitis to be commonest among the dermatitis $(55.31 \%){ }^{18}$ Several studies have shown increased prevalence of skin infections and infestations associated with lower parental education and occupation. ${ }^{12,21}$ In our study, $20.4 \%$ of mothers and $13.3 \%$ of fathers had lower educational achievement (<Class VI). Among these groups of parents, $60 \%$ of the children had infections and infestations while $40 \%$ had non-infective dermatoses. While in the group where the parental education was higher (>Class VI), non-infective dermatoses occurred slightly more $(51.1 \%)$ as compared to infections and infestations (48.9\%). Although this finding was not found to be statistically significant, it still shows a greater predisposition of infections and infestations in children whose parents have lower educational background. There was a positive correlation between infective dermatoses and maternal occupation, with infective dermatoses occurring more in children whose mothers were housewives. This could be because the literacy rate of housewives mothers are lower than the working mothers so they have less knowledge of hygienic practices, also mothers working outside the house bring in an additional source of income which helps in uplifting the economic status of the family thereby improving the socioeconomic state. There was an inverse relation of SES on infective dermatoses, with increase in SES associated with less chance of infective dermatoses. Similar finding has been quoted in other studies. ${ }^{12,17,21}$ Infections and infestations were seen to occur more where the number of rooms in the house were less, indicating overcrowding. Family size correlated positively with infections and infestations, showing that risk for infections and infestations increases with increase in the household population, which also correlates with overcrowding. ${ }^{12,16,17}$

Among the hygiene practices, sharing a common towel has been associated as a risk factor for infective dermatoses. ${ }^{22}$ However, our study failed to prove the same. Similarly, the 
frequency of bathing, changing underwear, nail trimming and use of soap for bathing did not show a significant association with infections and infestations in children.

\section{CONCLUSION}

Skin infections and infestations are a major source of morbidity in children. Socioeconomic status, parental education and maternal occupation play a significant role in childhood skin disease. Education and empowerment of women can be a strong forward step to reduce infectious skin disease in children which will reduce the public health burden of the country.

\section{ACKNOWLEDGEMENT}

We would like to thank Dr. Kalpana K. Malla for her guidance in writing this article.

\section{REFERENCES}

1. Sharma S, Bassi R, Sodhi MK. Epidemiology of dermatoses in children and adolescents in Punjab, India. J Pak Assoc Derma 2012; 22(3):224229.

2. Government of Nepal, Ministry of Health and Population, Department of Health Services Annual Report, 2009 and 2010. Raw Data Morbidity.

3. Shrestha DP, Gurung D, Rosdahl I. Prevalence of skin diseases and impact on quality of life in hilly region of Nepal. J Inst of Med 2012; 34(3):44-9.

4. Kumar A, Mishra A, Devkota S et al. Pattern of pediatric skin disorders in tertiary care center in western Nepal. Nepal J Dermatol Venereol Leprol 2010; 10:37-9.

5. Vora R, Bodiwala N, Patel S. Prevalence of Various Dermatoses in School Children of Anand District. National J Com Med 2012; $3(1): 100-3$

6. Karthikeyan K, Thappa DM, Jeevankumar B. Pattern of Pediatric dermatoses in a Referral Center in South India. Ind Pediatrics 2004; 41:373-7.

7. Sharma RC, Mendiratta V. Clinical profile of cutaneous infections and infestations in the Pediatric age group. Ind J Dermatol 1999; 44(4):174-8.

8. Ghosh A, Ghosh T. Modification of Kuppuswamy's socioeconomic status scale in context to Nepal. Ind Pediatrics 2009; 46(12):1104-5.

9. Blake KS, Kellerson RL, Simic A. Measuring Overcrowding in Housing. Econometrica, Inc. Bethesda, Maryland. U.S. Department of Housing and Urban Development. Office of Policy Development and Research; 2007: 1-24.

10. Saleh DA, Yassin S, Sabry HA, Abdelrazik MS. Priority families for health care according to family socio-demographic risks. J Public Health Epidemiol 2010; 2(6):138-46.

11. Mostafa FF, Hassan AAH, Soliman MI, Nassar A, Deabes RH. Prevalence of skin disease in infants and children in Al Sharqia Governorate, Egypt. Egyptian Dermatology Online Journal [Internet]. 2012 June [cited 2014 Feb 6];8(1):1-14. Available from :http://www.edoj.org.eg.

12. GK L, Bina T, Raphael L, Ramakrishnan SE, George B, Samson JF, VB. Prevalence and sociodemographic determinants of skin disease among lower primary school children in Calicut, Kerala. Available at www.imakmj.com/articles/02;185-190.

\section{Strength of the study}

This is one of the few studies in Nepal which has tried to identify the association of SES and personal hygiene on childhood skin disease.

\section{Limitations of the study:}

Nepal is a predominantly rural country. According to data from Nepal Population Report 2011, urban population comprises only $13.9 \%$ of the population. ${ }^{23}$ It is difficult to comment on the true prevalence of skin disease in children in our country, as this was a hospital based study and the subset of patients were mostly from urban community. This study was not able to identify the extent of problem in the rural population. In order to identify the prevalence of skin disease in children, a larger, community based study should be conducted.

13. Shrestha R, Shrestha D, Dhakal AK, Shakya A, Shah SC, Shakya H Spectrum of Pediatric Dermatoses in tertiary care center in Nepal. Nepal Med Coll J 2012; 14(2):146-8.

14. Kharel C, Pandey SS, Agrawal S, Bhattarai M. Socioeconomic and Nutritional Status of Children with Pyodermas. Nepal Journal of Dermatology, Venereology \& Leprology 2012; 10 (1):11-5.

15. Adhikari D. A Study on Health Status of Children Under Five Years of Age in a Rural Village of Eastern Part of Nepal. Journal of Nobel Medical College 2013; 2(1):49-54.

16. Sardana K, Mahajan S, Sarkar R, Mendiratta V, Bhushan P, Koranne $\mathrm{RV}$, et al . The Spectrum of Skin Disease Among Indian Children. Pedia Dermatology 2009; 26(1):6-13.doi:10.1111/j.15251470.2008.00814.x

17. Memon KN, Soomro RA, Ansari MS. Pattern of skin diseases in patients visiting a tertiary care health facility at Hyderabad, Pakistan. J Ayub Med Coll Abbottabad 2011; 23(4):37-39. Available at http:// www.ayubmed.edu.pk/JAMC/23-4/Khalida.pdf.

18. Balai M, Khare AK, Gupta LK, Mittal A, Kuldeep CM. Pattern of Pediatric Dermatoses in a Tertiary Care Centre of South West Rajasthan. Indian J Dermatol [Internet].2012 Jul-Aug [cited 2014 Feb 6];57(4):275-278. doi:10.4103/0019-5154.97665.

19. Hussain M, Hussain M, Akhter N, Farzana N. The spectrum of childhood dermatosis in the outpatient department of a tertiary care paediatric hospital. DS (Child) H J 2011; 27(2):59-63.

20. Negi KS, Kandpal SD, Parsad D. Pattern of Skin Diseases in Children in Garhwal Region of Uttar Pradesh. Ind Pediatrics 2001; 38:77-80.

21. Oyedeji OA, Okeniyi JAO, Ogunlesi TA, Onayemi O, Oyedeji GA, Oyelami OA. Parental Factors Influencing the Prevalence of Skin Infections and Infestations Among Nigerian Primary School Pupils. The Internet Journal of Dermatology (ISSN: 1531-3018) 2006 [cited 2014 Feb 6]; 3(2).doi:10.5580/1db6.

22. Amoran OE, Runsewe-Abiodun OO, Mautin AO, Amoran IO. Determinants of dermatological disorders among school children in Sagamu, Nigeria. Educational Research [Internet] (ISSN: 2141-5161) 2011 Dec [cited 2014 Feb 6];2(12):pp.1743-48. Available online: http://www.interesjournals.org.

23. Government of Nepal, Ministry of Health and Population, Population Division. Nepal Population Report 2011. 97 p. 